\title{
THE OTHERS FROM ACROSS THE SEA - EASTERN EUROPEANS AND EASTERN EUROPE IN MODERN NORWEGIAN LITERATURE
}

\author{
Karolina DROZDOWSKA (University of Gdańsk) \\ ORCID: 0000-0002-1064-0111
}

\section{The Premises}

The year 2004, when Central and Eastern European countries joined the European Union, was also the beginning of a process that brought a significant demographic change for the Scandinavian region whose labour markets became accessible for the citizens of the "new" EU countries. This led to a large wave of labor migration, which in turn resulted in growing cultural and economic exchange. Poles are at the moment the largest national minority in Norway, followed by Lithuanians. ${ }^{1}$ This demographic change that took place over the last 15 years has also had a considerable impact on Norwegian social, political and cultural life. Migrants from Eastern Europe were "foreign" in at least two different senses - they came from another country, but also from another reality, a reality from "beyond the Iron Curtain" to which the Scandinavian citizens for years had had limited access. It is therefore natural that this "meeting with the Other / the Foreign" which has been taking place on such a large scale since 2004 also translates into literature.

The aim of this paper is to present how Eastern Europeans and Eastern Europe are presented in modern Norwegian prose - I shall concentrate on Norwegian texts published in the years 2004-2017 representing both the so-called "popular" literature, for example crime fiction, and the works of reputed authors. The examples I analyze are both literary representations of the Eastern European "Foreigners/Others" in

\footnotetext{
1 Innvandrere og norskfødte med innvandrerforeldre. Statistisk Sentralbyrå, 2019, https://www.ssb.no/innvbef.
} 
Norway and the countries they come from - concentrating mainly on Poland and the Baltic countries. It is my goal to show how and why countries situated in such close geographical proximity to Scandinavia, as well as their citizens, can still be depicted as "exotic" in literary works. ${ }^{2}$

Before moving on to the analysis itself, it is necessary to focus on the theoretical framework of this paper, and, at the same time, to try to answer the questions: How to define "Eastern Europe"? What may this term mean to the Norwegian authors whose works are going to be presented in the next sections of this paper? And, perhaps, most importantly: Can one define a set of rules in accordance to which the literary images of Eastern Europe and Eastern Europeans in modern Norwegian literature are constructed?

\section{Imagining Eastern Europe}

"From Stettin in the Baltic to Trieste in the Adriatic, an iron curtain has descended across the Continent," said Winston Churchill in a speech given at Westminster College on March 5, 1946. ${ }^{3}$ Thus was the division of post-World War II Europe established. The metaphorical (and, later, quite literal in the form of the Berlin Wall) curtain implies a very clear and very definite division between the West and the East. At the same time, this barrier can seem quite impenetrable - it is not only very difficult to travel beyond the Iron Curtain, but also virtually impossible to see what happens on the other side. Larry Wolff, who starts his book Inventing Eastern Europe (1994) with Churchill's famous quote and then proceeds to reflect upon the "shadow" cast by the infamous barrier, puts it in the following words: "In the shadow it was possible to imagine vaguely whatever was unhappy or unpleasant, unsetting or alarming, and yet it was also possible not to look too closely, permitted even to look away - for who could see through an iron curtain and discern the shapes evolved in the shadow?"4 Thus, Eastern Europe became a mysterious space, inaccessible not only physically, but also intellectually, and, at the same time, a space one did not feel obliged to examine closely, reflect over or concern oneself with too much. ${ }^{5}$

Interestingly, as Wolff points out, this situation did not necessarily change after 1989 or 1991, that is, after the fall of the Berlin Wall - the physical symbol of the Curtain. Eastern Europe was still, in the eyes of many Westerners, a place where "shapes evolved in the shadow." One might extend this reflection by adding that, despite the "map adjustments" of 2004 and 2007 (when Eastern and Central European

\footnotetext{
${ }^{2}$ Similar studies have previously been conducted by researchers working with Danish literature (Sylwia Izabela Schab, Palimpsest polski. Reprezentacje Polski I Polaków w duńskich relacjach podróżniczych (Poznań: Wydawnictwo Naukowe UAM, 2018); Sylwia Izabela Schab, Wschodnie tropy zbrodni. O Polsce we współczesnej duńskiej powieści kryminalnej (Gdańsk: Wydawnictwo Uniwersytetu Gdańskiego, 2018)) or Nordic Noir as a film genre (Anna Estera Mrozewicz, Beyond Eastern Noir (Edinburgh: Edinburgh University Press, 2018)).

${ }^{3}$ See for example: Sir Winston Churchill - Sinews of Peace (Iron Curtain) Speech. Speech given at Westminster College (Fulton MO) on March 5, 1946, https://www.youtube.com/watch? $\mathrm{v}=5 \mathrm{QuSXZTo3Uo.}$

${ }^{4}$ Larry Wolff, Inventing Eastern Europe (Palo Alto: Stanford University Press, 1994), 1.

${ }^{5}$ It is also an interesting that the notion of the mere existence of Eastern or Central Europe is still discussed by modern researchers. In her book on Central Europe, Weronika Parfianowicz-Vertun starts the narration with a simple question: "Does Central Europe exist?" (Weronika Parfianowicz-Vertun, Europa Środkowa w tekstach i działaniach (Warszawa: Wydawnictwo Uniwersytetu Warszawskiego, 2016), 13). This proves the ontological ambiguity of the region that not only Westerners, but also the inhabitants of Eastern/Central Europe themselves, are confronted with.
} 
countries became part of the European Union and later, Schengen Area), this optics may - as we shall see in the next sections of this article - still prove itself to be very relevant. Wolff argues that the fall of the Berlin Wall did not result in any significant change in the perception of the "East" by the "West" for the simple reason that the idea of the Iron Curtain is much older than the Curtain itself and dates back to the $18^{\text {th }}$ or even $17^{\text {th }}$ century: "The Enlightenment had to invent Western Europe and Eastern Europe together, as complementary concepts, defining each other by opposition and adjacency." This idea of "opposition and adjacency" is key to understanding how Eastern Europe is "invented" according to Wolff; since it is a space where "shapes evolve in the shadow," a space one is neither tempted or feels in any way obliged to examine particularly closely, one has to find a means to obtain an understanding of it in another way. And, since "the East" has, for some three or four hundred years, been defined by the "West" as "Europe, but not Europe," an ambiguous and mysterious space, the image of "otherness" is constructed by means of contrasts. In short, "inventing" Eastern Europe, according to Wolff, means defining this space as antagonistic to Western Europe, creating an intellectual construct where the East is what it is because it is not the West.

This, in turn, bears a close resemblance to what Edward W. Said writes about the Orient-Occident dichotomy in his classical work, Orientalism (originally published in 1978). Said, adapting a global approach and taking colonial history as a starting point for his reflection, points out that the Orient was constructed by the Occident "as its contrasting image, idea, personality, experience." 8 This construction and a certain way of thinking is what constitutes the phenomenon of orientalism, which, in short, serves as "a Western style for dominating, restructuring and having authority over the Orient." One can therefore conclude that Wolff's perception of the Western EuropeEastern Europe dichotomy is based on the same general idea as the concept of the Occident-Orient dualism presented by Said in the 1970's. Eastern Europe has thus, in a way, become the new Orient for the West, in a process that has little to do with colonialism in the term's traditional meaning, but in which domination and authority still play a considerable role. ${ }^{10}$

This intellectual "recalibrating" of the map allows Eastern Europe to be perceived not only as an ambiguous space, but as one that is also "oriental" or even "exotic." In my analysis, I shall try to argue that the image of Eastern Europe and Eastern Europeans in modern Norwegian literature is built precisely on this way of thinking — and presented as an opposition to a typical construct of what Norway and Norwegians (and, in a broader sense - what Western Europe and Western Europeans) are and what they represent.

\section{Background and Material}

As stated previously, Poles and Lithuanians are at the moment the biggest national minorities in Norway, with, respectively, over 98 and a half and over 39 thousand

\footnotetext{
${ }^{6}$ Ibid, 5 .

${ }^{7}$ Ibid, 7.

${ }^{8}$ Edward W. Said, Orientalism (New York: Random House, 1979), 1-2.

${ }^{9}$ Ibid, 3 .

${ }^{10}$ It can of course be discussed whether or not Said's Orientalism has become outdated or to what extent the book has exhausted its interpretative possibilities. One of the more recent publications which engages in discussion with Said's text is Occidentalism: The West in the Eyes of Its Enemies by Ian Buruma and Avishai Margalit (2004), a kind of a philosophical spoof of Orientalism.
} 
"immigrants" "11 living in the country. ${ }^{12}$ These groups constitute Norway's "new immigration," that is, people who came to the country post 2004, mostly in search of new career opportunities. This - rather rapid - demographic change has, as one might expect, had an influence on the Norwegian cultural life. Eastern Europeans and perhaps especially the Poles, since they represent the largest minority group became present in the media, in political and sociological discourse (Ingrid Brekke's book from 2019 serves as a good example of how Norwegians try to "explain" Poland and Poles), but also in popular culture and literature.

As an example of this phenomenon, one can name two television series produced by NRK $^{13}$ in the years 2013 and 2014/2015. The first one, a docuseries entitled Brakkefolket [The Barracks People] ${ }^{14}$ consists of one season with three episodes, broadcast in 2013 and 2014. It tells the story of Polish construction workers coming to Norway and living in barracks, that is, temporary quarters built to house a (mainly East European) labor force. The Poles depicted in the series live in what the producers call "brakkebyen," a "barrack town," constituting a form of an exotic micro-society within the Norwegian cultural landscape, with their own language, traditions and way of life which differs considerably from what can be perceived as common in Norway. The second television series which takes up the topic of the Polish minority is the fictional Kampen for tilverelsen [A Struggle for Life],${ }^{15}$ consisting of two seasons (18 episodes in total), broadcast between 2014 and 2015. Unlike Brakkefolket, this series tells the story of a young academic, Tomasz, who travels to Norway in order to find his father, and, also, a better paying job. He becomes a manual laborer, taking up work he knows nothing about. The series plays not only on stereotypes about Poles, but also constitutes a reflection on Norwegian society.

The post 2004 demographic shift has also, as a natural consequence, had a considerable influence on literature. Eastern Europe and Eastern Europeans became increasingly popular motifs picked up by the Norwegian authors, regardless of their preferred genre. In my analysis, I have decided to concentrate on six books, all of them prose. The selected texts are as follows:

Crime fiction: ${ }^{16}$

- Jørn Lier Horst, Vinterstengt, published by Gyldendal in 2011, translated into English by Anne Bruce as Closed for Winter, published by Sandstone Press Ltd. in 2013.

${ }^{11}$ In Norwegian: "innvandrere." This term refers to a person who was not born in Norway and whose parents were not born in Norway.

${ }^{12}$ Innvandrere og norskfødte med innvandrerforeldre, Statistisk Sentralbyrå, data per March 2019.

${ }_{13}^{13}$ Norwegian government-owned radio and television public broadcasting company.

${ }^{14}$ Brakkefolket, NRK, 2013. https://tv.nrk.no/serie/brakkefolket.

${ }_{16}^{15}$ Kampen for tilvarelsen, NRK, 2014/2015.

${ }^{16}$ When analyzing the representations of Eastern Europe and - especially - Eastern Europeans in crime fiction, one should take one essential aspect into consideration: each crime novel is based upon a sort of conventional plan, format or scheme - someone has to be the "criminal" or "the bad guy." A certain group is always the place the antagonists are recruited from (see for example books by Stanko Lasić (1976) or Mariusz Czubaj (2010)). Those conventions may be of greater importance than the relations to "the Other." The representation of Eastern Europe and Eastern Europeans in Norwegian crime fiction is nevertheless very interesting and worth closer analysis, provided one takes this reservation into consideration. 
- Gard Sveen, Blod $i$ dans [Dancing Blood $],{ }^{17}$ published by Vigmostad \& Bjørke in $2016 .^{18}$

Novels:

- Lars Saabye Christensen, Modellen, published by Cappelen in 2005, translated into English by Don Bartlett as The Model published by Arcadia Books in 2007.

- Nina Lykke, Nei og atter nei [No, a Hundred Times No], published by Forlaget Oktober in 2016.

- Anne B. Ragde, Liebhaberne [Honour Thy Father], published by Forlaget Oktober in 2017.

Short stories:

- Mikkel Vika, "Alle vil til Auschwitz" [Everyone Wants to Go to Auschwitz] from the collection Nowa Huta, published by Vigmostad \& Bjørke in 2016.

The reasons I chose those particular titles are that they a) represent different genres (crime fiction, novels and a collection of short stories), b) were published after the year 2004, and finally, c) present a depiction of Poland and Poles, but also of other Eastern European countries and their inhabitants, such as Lithuanians, Russians or Estonians. They are either written by critically acclaimed and awarded authors (Christensen, Lykke) or by those who are extremely popular (Horst, Sveen, Ragde). I have also chosen to include Vika's short story in my analysis, as it is a part of an entire collection devoted exclusively to Eastern Europe and Eastern Europeans, and, therefore, is a very interesting subject for this discussion.

I have decided to divide my analysis into two main parts. The first part will be devoted to how Eastern Europe is presented as a space in the works listed above. The second one will concentrate upon the images of Eastern Europeans as people/characters in the texts.

\section{Constructing Images of Eastern Europe}

Before moving on to an analysis of the dichotomic categories constituting the image of Eastern Europe in the selected texts, one initial remark must be made. This space is generally depicted as terra incognita, the unknown territory the characters of the book have no or very little idea about. In his review of Vika's short stories (entitled "Harde liv i Øst-Europa" ["The Hard Life in Eastern Europe"]), Ola Jostein Jørgensen writes that all of the texts are set in "exotic" landscapes, taking into consideration they were written by a Norwegian. ${ }^{19}$ The readers of the texts analyzed herein might indeed feel that the characters who travel to Eastern Europe visit very remote places - spaces they know little about and of which they do not feel the need to have a basic understanding. In both of the crime fiction novels selected for this analysis, the protagonists must, at some point, visit Lithuania in order to solve the case they are working on. Jørn Lier

${ }^{17}$ The English titles of the books that have not been translated into English are either (in the cases of Lykke and Ragde) the titles proposed by the authors' agent, Oslo Literary Agency (see https://osloliteraryagency.no/) or (in the cases of Sveen and Vika) my own translations. All excerpts from books that have not been translated into English are quoted in my own translation - KD.

${ }^{18}$ It is worth mentioning that the events depicted in the book take place in the year 2005, although this fact does not have any considerable impact on the validity of this analysis.

${ }^{19}$ Ola Jostein Jørgensen, Harde liv i Øst-Europa, Littkritikk, 2016. https://www.littkritikk. no/single-post/2016/09/12/Harde-liv-i-\%C3\%98st-Europa. 
Horst's William Wisting reflects upon his journey while sitting on a plane: "He leaned back and contemplated what he knew about Lithuania. Only a few days ago he couldn't have placed it on the map. He was shamefully ignorant of the country, although it was less than two hours by air from Oslo." 20

In this case, we can speak about a sort of a geographical relativity: Lithuania is situated in close proximity to Norway on the map, but at the same time seems like a land "far, far away." Wisting admits his own ignorance to himself, but, at the same time, it is made clear to the audience that his ignorance is something "shameful." The detective is aware of the fact that his lack of knowledge about the land he is travelling to might be a setback for the investigation he is working on. Gard Sveen's Tommy Bergmann presents a slightly different approach. When visiting Vilnius, he goes to a bar, where he meets a prostitute and engages in conversation with her:

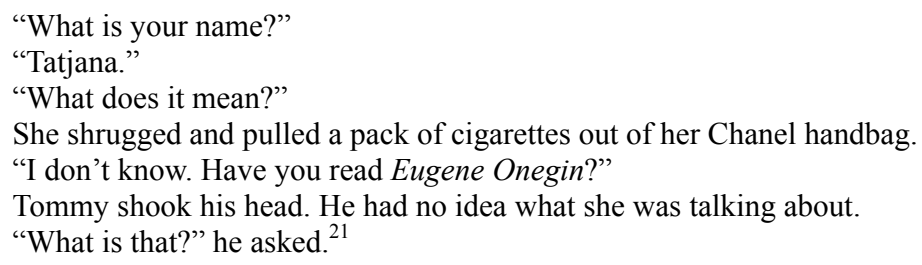

Unlike Wisting's, Tommy Bergmann's ignorance is rather shameless. He is surprised by the woman's first name Tatjana, very popular in large parts of Europe, and asks what it means, almost as if he was expecting that each Eastern European name has its own meaning, perhaps like the names of some of the indigenous peoples of North America. Secondly, he has clearly never heard of Alexander Pushkin, one of the greatest writers in European history. The most remarkable fact here is that Bergmann sees absolutely no problem in his ignorance, obviously paired with a considerable amount of arrogance.

Both the characters feel that, as Larry Wolff puts it, "it is possible not to look too closely, permitted even to look away." Eastern Europe thus becomes a geographically ambiguous space, a place close yet far away, an exotic and unknown land.

In my analysis, I have chosen to concentrate on three sets of dichotomies that constitute the representation of this space in the texts: modernity-backwardness, wealth-poverty and rationality-irrationality.

\section{Modernity-backwardness}

This binary opposition is perhaps most apparent in the texts analyzed herein. Eastern Europe is what it is because this space, in contrast to modern Norway, can be described as backward, perhaps even "frozen" in its post-Soviet reality. Some of the representations of Eastern European countries in the selected texts present an alternative, imagined reality, quite remote from what the described spaces actually look like. Large parts of the plot in Lars Saabye Christenesn's The Model take place in Estonia. The following excerpt shows how the reality of this country (per the year 2005) is presented in the novel:

[...] two people will soon wake up, two children, they are only children, in a shed on a disused, tumbledown collective farm. The boy wakes up first. He is freezing. The skin on their hands has cracked in the course of the night [...]. It is minus fifteen degrees. It

\footnotetext{
${ }^{20}$ Jørn Lier Horst, Closed for Winter, E-book (Inverness: Sandstone Press, 2017), Chapter 39.

${ }^{21}$ Gard Sveen, Blod i dans (Bergen: Vigmostad \& Bjørke, 2016), 93.
} 
is Christmas Eve. He turns to his sister. [...] She has tied plastic bags over her feet.

$[\ldots]^{22}$

In Christensen's case, one has to additionally take into consideration that the author often introduces elements of magical realism in his books, so it might not be absolutely clear whether this excerpt is a presentation of actual Estonia AD 2005 or, perhaps, an alternative time and space reality where orphaned children are actually forced to sleep in "tumbledown collective farms." In the case of Mikkel Vika's short stories, however, there is little to no doubt. The author makes it very clear that he sets his texts in modern Eastern Europe. In the following example, the protagonist drives to Balice, an airport located outside the Polish city of Kraków:

The roads are getting better. Fewer timber carts, more lanes, there they are, illuminated, bearing a message of hope. Here and there groups of tall blocks of flats. I am travelling through satellite towns, dilapidated industrial buildings shout out towards me, all of them identical and sad. ${ }^{23}$

Looking aside from the concept of "timber carts" (org. tømmerkjerrer) on a highway outside one of the major Polish cities in the year 2016, the first thing that draws the reader's attention seems to be the post-communist heritage of the country: the blocks of flats, dilapidated industrial buildings and the fact that there is a form of a depressing uniformity in the landscape. This post-Iron Curtain heritage is predominant in the images of Eastern Europe in the texts analyzed herein, manifesting itself also in the next two pairs of dichotomies.

\section{Wealth-poverty}

Eastern Europe is presented as a place characterized by poverty, which seems to be the result of its post-communist history. Wealthy Norwegians are often shocked by the living conditions in the countries they visit. Their reactions towards Eastern Europe's economic condition can be described as condescending. They, the "rich" Westerners, demonstrate a sense of patronizing superiority in their contacts with the "poor" inhabitants of the lands beyond the metaphorical Iron Curtain. An example of this phenomenon can be found in Horst's crime novel, where the protagonist walks around Vilnius and buys a souvenir from a child street seller:

The girl searched through her pocket for change, but Wisting signaled that she could keep the money. It was a useless form of benevolence, but he sacrificed his principles to brighten this late hour for the little mite. Perhaps she would remember it even though the money would soon be gone. ${ }^{24}$

In Vika's short story, Eastern European poverty is described "from the inside," as the protagonist is Polish himself - he is forced to travel to Norway in order to find work and be able to support his family. The image of poverty presented through the eyes of this character is both depressing, hopeless and strongly exoticized. The following passage does not describe the actual financial conditions of the labor migrants' families in Poland, but rather the Norwegian construction or image of what those conditions

${ }^{22}$ Lars Saabye Christensen, The Model, E-book (Mount Pleasant: Arcadia Books, 2011), Chapter 18. 26-27.

${ }^{23}$ Mikkel Vika, “Alle vil til Auschwitz.” Nowa Huta (Bergen: Vigmostad \& Bjørke, 2016),

${ }^{24}$ Horst, Closed for Winter, Chapter 43. 
might look like. Here, the protagonist reflects upon his situation while looking at his small daughter:

I can hold her, tell her everything is going to be all right again. But I cannot promise that she will be warm when winter comes, that gas will be flowing in the pipes. It's expensive to be poor, no one wishes to be cold. I am being told it's temporary. I don't know what 'temporary' means. ${ }^{25}$

Even when Eastern wealth is described in these texts, it is always caricatural or even cartoony in its nature - almost as a parody of "proper" Western wealth, and it invariably co-exists with poverty, as both phenomena are presented as two aspects of the same degeneration, often leading to criminal acts or other transgressions of morality in its "Western" sense. While exploring Vilnius, Horst's detective reflects upon the city's economic diversity: "Open prostitution and poverty existed side by side with rich men emerging from expensive cars in the company of long-legged blondes. He understood how those who saw no future for themselves in this city would choose to steal in other countries." 26

In Nina Lykke's No, a Hundred Times No, two of the main characters, Jan and Hanne, travel to Turkey for a holiday, where they are confronted with the Russian nouveau riches:

He stood there in the lobby of that expensive hotel, on a shiny marble floor, surrounded by Russians and their surgically altered wives in tight leopard dresses [...] Jan looked at the Russian women at the other tables. With their swollen lips and enormous tits, they resembled monsters and beasts, and he felt the oysters grow in his mouth. ${ }^{27}$

The caricatural wealth in its Eastern European version is, as we can see, not only demoralizing, but also, in a way, dehumanizing, distasteful or even borderline disgusting, almost as if Eastern Europeans did not possess the necessary competence to manage their excessive financial resources. The two passages presented here also associate wealth with women of a certain appearance - long-legged blondes in Horst's crime fiction and "surgically altered" (org. plastisk-opererte) wives of rich businessmen in Lykke's novel. This image can be perceived as another contrast the concept of Eastern Europe is built upon in the texts analyzed herein - the idea of the objectified women, reduced to status symbols, is constructed as an opposition to the Scandinavian (and generally Western) idea of gender equality. Is almost as if the entire Eastern reality was governed by an alternative, irrational logics.

\section{Rationality-Irrationality}

Just like backwardness and poverty, Eastern irrationality is also an element of the postcommunist heritage. The lands beyond the Iron Curtain are perceived as spaces where the Western straightforward logics does not apply. Instead, they constitute almost Kafkaesque spaces, where actions do not cause reactions as they would in the rational Western world, a land of incomprehensible absurdities. In Christensen's The Model, one of the characters tells a story of a family member from communist times. His grandfather took part in an absurd experiment to grow maize in Estonia. The crops naturally failed because of the country's harsh climate, but the Soviet officials who

\footnotetext{
${ }^{25}$ Vika, "Alle vil til Auschwitz," 22.

${ }^{26}$ Horst, Closed for Winter, Chapter 43.

${ }^{27}$ Nina Lykke, Nei og atter nei. (Oslo: Forlaget Oktober, 2016), 227 and 229.
} 
visited the fields refused to accept this fact. Pulling sterile stalks from the ground, one of them remarked: “[...] I knew it, you idiots, you planted the seed upside down!"; "[...] And do you know what my grandfather said to the men from the Kremlin?"; "[...] I thought so. You idiots. It's you who are standing on your heads!"; “[...] What happened to your grandfather then?"; "What do you think? He was sent to Narva to dig peat for the electricity board until he died.,"28

This excerpt is a good example of how the images of Soviet and post-Soviet irrationality are constructed in the texts analyzed herein: an absurd (and utterly stupid) experiment is met with an equally absurd commentary, which is in turn met with an even more absurd (and unreasonably cruel reaction. This irrationality seems to have outlived communism itself, even though it clearly stems from the system. During his tour of Vilnius, Horst's detective visits a huge illegal market. He is beyond himself with surprise when he learns that the authorities do nothing to close it down: "Nearly seventy thousand people live off that turnover. If we were to close Gariunai, there would be a social catastrophe. [...]"; "Wisting was speechless. An entire economy was based on trading of smuggled goods and stolen property." 29

It seems as though the communist system still lives on in Eastern Europe, regardless of the political changes. The mindset of the people remains "communistically" unreasonable while Marx's infamous specter haunting Eastern Europe is still ominous and perhaps even potentially dangerous - for Westerners. In Sveen's crime novel, Tommy Bergmann meets a Lithuanian university professor who answers some of the questions the detective has with regards to the case he is working on. The professor seems suspiciously polite and converses in flawless English with the Norwegian policeman: "Tommy remembered something Fredrik Reuter once told him: 'Watch out for Eastern Europeans who speak perfect English. The probability that they in reality are spies, is almost one hundred per cent'., 30

All three of the dichotomies described in this section of the paper - modernity vs. backwardness, wealth vs. poverty and rationality vs. irrationality - allow Eastern Europe to be constructed as "a twilight zone," where, as Wolff describes it, "shapes evolve in the shadows." This space is so ambiguous and mysterious that it might even become a form of a portal, a gateway between two worlds - the real and the surreal. The entire plot of Christensen's The Model revolves around a painter who is losing his sight. The character meets an old school friend (who later on turns out to be the Devil), who promises to give him his eyesight back. It turns out, however, that the terms of this Mephistophelian contract cannot be fulfilled in Norway - the protagonist has to travel to Estonia, almost as if the Devil's forces were stronger there. It is perhaps worth mentioning that this pattern of events can also be found in earlier Norwegian literary texts, as, for example, in Dag Solstad's Novel 11, Book 18 (originally published in 1992, with the English translation published in 2008), ${ }^{31}$ where the protagonist travels to Lithuania in order to undergo a highly shady procedure — a scam — which puts him in a wheelchair of his own free will.

After having reflected upon the construction of space, it is only natural to move on to the construction of the people and see who the inhabitants coming from the lands beyond

\footnotetext{
${ }^{28}$ Christensen, The Model, Chapter 15.

${ }^{29}$ Horst, Closed for Winter, Chapter 47.

${ }^{30}$ Sveen, Blod i dans, 93.

${ }^{31}$ Dag Solstad, Novel 11, Book 18 (London: Harvill Secker, 2008).
} 
the Iron Curtain are. In the next sections, I shall concentrate on how the image of Eastern Europeans as national minorities in Norway is constructed in the selected texts.

\section{Constructing Images of Eastern Europeans}

An initial remark that must be made while discussing these constructions is that Eastern Europeans seem to be divided into two different groups: the ones who "come and stay" (mainly labor force), that is, the ones who spend longer periods of time in Norway or even live there, and the ones who "come and go" (mainly criminals). Both groups seem to have a clear economic motivation, which also results from the contrasts between the West and the East. Sveen's Bergmann reflects upon the situation of Lithuanian citizens: " "No wonder they wanted to join the EU,' said Tommy. 'Or that the big countries wanted them to join. The labor force can't cost much over here'.",32

Eastern Europeans coming to Norway are almost automatically perceived as cheap labor, taking up jobs such as construction work (stereotypically for males) and cleaning (stereotypically for females). One of Lykke's characters, Ingrid, considers her unique situation - she, unlike her neighbors, takes care of everyday chores herself: "She paid the bills on time, recycled the rubbish and cleaned the house herself, unlike her friends and neighbors, as most of them had a cleaning person from Poland, the Philippines or Ukraine." 33

One can therefore see that Eastern Europeans (together with some other nationalities) constitute a separate "class" in Norway and that this situation is more or less natural and obvious. They are people coming into the country to earn money doing physical work. The motivation of the other group, that is Eastern Europeans who "come and go" is also of an economic nature - they want to improve their financial situation, but by means of committing crimes. Horst's Wisting considers the results of extending the EU's borders in 2004:

This same agreement had imported crime to the Nordic countries. The extension of the EU in 2004 provided criminals with a huge market, and after the East European countries joined Schengen in 2007, there had been a dramatic increase in crimes against property. $^{34}$

Interestingly, the Eastern European criminals in the texts presented herein seem to have a sense of morality which differs considerably from the Western, that is, "logical" and "reasonable" one. When a Lithuanian criminal is asked why he came to Norway to commit crimes, he answers honestly:

"Why did you go to Norway?" [...] It's better to steal from Norway, because it's a wealthy country, than a poor country where people don't have so much. Norway doesn't notice if a person steals a hundred thousand kroner. ${ }^{35}$

This conversation is very fascinating, as it not only shows that the Eastern European way of thinking is driven by irrationality generally characterizing the region the criminal comes from, but shows that the Easterner himself is aware of the binary contrasts between his country and Norway and perceives it as a general defining factor.

\footnotetext{
${ }^{32}$ Ibid, 76

${ }^{33}$ Lykke, Nei og atter nei, 19-20.

${ }^{34}$ Horst, Closed for Winter, Chapter 40.

${ }^{35}$ Ibid, Chapter 52.
} 
Let us take a closer look on how citizens of Eastern European countries are presented as a labor force. This group has a set of common features: they are mostly men, separated from their families they left at home. Their goal is to make as much money as possible and to go back to their home countries. That is why they are very hardworking and diligent. In Anne B. Ragde's Honour Thy Father, one of the characters, Erlend, renovates a villa in Copenhagen together with his partner, Krumme. They chose Polish construction workers because of the traits mentioned above:

$[\ldots]$ and if they rather wanted a free Sunday, they could take a rest and sleep as long as they wanted or get drunk out of their minds, it was entirely up to them and their own wallets. But they weren't particularly happy with free time, free time was reserved for Poland. ${ }^{36}$

The Polish team is also willing to disregard the strict Scandinavian regulations concerning, among others, limited work time. The Eastern Europeans seem also to be open for unorthodox solutions when it comes to formalities, official permits and so on: "[...] it wouldn't look good if it was discovered that BT's editor-in-chief took advantage of illegal labor force. Or ecological labor force, as Erlend preferred to call it."; "[...] It was absolutely out of the question to use a Danish company, their children would be teenagers before the villa would have been finished, and there would be constant moaning about work time and break time and securing the workplace and retirement points and the devil and his great-grandmother. Thank heavens for Eastern Europe.",37

Another characteristic trait of the Polish workers is that they do not speak any Norwegian (and very limited English). In her novel, Ragde introduces a very interesting character - a Finnish foreman who serves as a boss for the Polish workers. The Finn plays the role of an "intercultural mediator" between the Eastern and the Western cultures, he himself coming from a space which is "neither East nor West." He is, like the Poles, presented as exotic, but to a considerably lesser extent. For example, he does speak any English, even though his command of the language is not exceptionally good:

The foreman at the villa was a Finn who spoke a little English, and he was also going, Finns are after all, as well as Poles, known for their ability to keep down considerable amounts of vodka. - Today we drink for dead friend. So tomorrow no good day also, Toivo had explained. ${ }^{38}$

What Ragde seems to put exceptionally large pressure on is the Poles' strange and highly unappetizing eating habits. The Finnish foreman is also slightly more civilized when it comes to this aspect:

Two of the Poles ate entire, raw onions like apples, without a single tear, while Erlend's eyes watered from merely looking at them. Some days he would bring a bag of boiled eggs from home, the Poles peeled them and popped them into their mouths like candy drops, Toivo was more delicate in his eating habits, he divided each egg in half with his teeth. ${ }^{39}$

\footnotetext{
${ }^{36}$ Anne B. Ragde, Liebhaberne (Oslo: Forlaget Oktober, 2017), 259.

${ }^{37}$ Ibid, 260.

${ }^{38}$ Ibid, 43. The line in italics is taken directly from the original text (it was also written in "English" in the original version).

${ }^{39}$ Ibid, 119.
} 
The motifs of Poles eating raw onions "like apples" comes back again in Ragde's next book, Datteren [The Daughter] from 2019. ${ }^{40}$ Since this manner of eating vegetables is in no way typical of the Polish population, it can be perceived as a form of exoticization, or building an image of an entire nation on unclear presumptions and prejudice. One can ask the question: will Eastern Europeans forever be "sentenced" to the metaphorical "raw onion" in Norwegian literature? The answer, luckily, might be: not necessarily.

\section{Conclusion: The Old, the New and Agency}

In order to find an answer to the question posed above, one should consider how other national minorities are presented in modern Norwegian prose. Norway experienced, after all, large waves of migration long before 2004, and a considerable number of the country's citizens has, among others, Middle Eastern or Pakistani roots. Members of those ethnical groups are also frequently represented in literature, and, what is interesting, they are usually not described as "others" or "foreign." Unlike Eastern Europeans, they have agency and are presented as subjects rather than objects. In Gard Sveen's novel, presenting a rather unfavorable image of Lithuanians, Pakistani youngsters help the protagonist when he is in trouble, ${ }^{41}$ an act Bergmann welcomes with respectful gratitude. His colleague, Susanne, considers where in Oslo she and her teenage daughter should live, and thinks about neighborhoods typically associated with the "old" immigration. "Maybe she would move back to Grønland or Tøyen. The more immigrants, the better, she thought." 42

One can therefore see that geography and maps are indeed a relative concept. In this text, people coming from Asia seem to be less exotic for Norwegians than the ones born in countries just across the Baltic Sea. The main factors having some impact on the situations seem to be time and experience.

This article is an attempt to describe a phenomenon in progress. One can put forward the hypothesis that the image of Eastern Europe and Eastern Europeans in Norwegian literature will transform, evolve and develop in time, parallelly to the development and evolution of the intercultural contacts between the people representing the two different spaces described in this paper. Literature might be one of the key factors in this exchange, potentially leading to the fall of the "Iron Curtain," not only literally, but also metaphorically, a shift in our binary way of thinking about the West and the East.

\section{BIBLIOGRAPHY}

\section{Printed resources}

Brekke, Ingrid. Polen. Aske og diamenter. Oslo: Humanist forlag, 2019.

Buruma, Ian and Margalit, Avishai. Occidentalism: The West in the Eyes of Its Enemies. London: Penguin Press, 2014.

Christensen, Lars Saabye. Modellen. Oslo: Cappelen, 2015.

Christensen, Lars Saabye. The Model. E-book, transl. Don Bartlett. Mount Pleasant: Arcadia Books, 2011.

\footnotetext{
${ }^{40}$ Anne B. Ragde, Datteren (Oslo: Forlaget Oktober, 2019), 30 and 191.

${ }^{41}$ Sveen, Blod i dans, 13.

${ }^{42}$ Ibid, 227.
} 
Czubaj, Mariusz. Etnolog w mieście grzechu. Gdańsk: Oficynka, 2010.

Horst, Jørn Lier. Vinterstengt. Oslo: Gyldendal, 2011.

Horst, Jørn Lier. Poza sezonem, transl. Milena Skoczko. Sopot: Smak Słowa, 2015.

Horst, Jørn Lier. Closed for Winter. E-book, transl. Anne Bruce. Inverness: Sandstone Press 2017.

Lasić, Stanko. Poetyka powieści kryminalnej, transl. Magdalena Petryńska. Warszawa: Państwowy Instytut Wydawniczy, 1976.

Lykke, Nina. Nei og atter nei. Oslo: Forlaget Oktober, 2016.

Lykke, Nina. Nie, po prostu nie, transl. Karolina Drozdowska. Warszawa: MUZA, 2018.

Mrozewicz, Anna Estera. Beyond Eastern Noir. Edinburgh: Edinburgh University Press, 2018.

Parfianowicz-Vertun, Weronika. Europa Środkowa $w$ tekstach $i$ działaniach. Warszawa: Wydawnictwo Uniwersytetu Warszawskiego, 2016.

Ragde, Anne B. Liebhaberne. Oslo: Forlaget Oktober, 2017.

Ragde, Anne B. Kochankowie, transl. Ewa M. Bilińska and Karolina Drozdowska. Sopot: Smak Słowa, 2018.

Ragde, Anne B. Datteren. Oslo: Forlaget Oktober, 2019.

Said, Edward D. Orientalism. New York: Random House, 1979.

Schab, Sylwia Izabela. Palimpsest polski. Reprezentacje Polski i Polaków w duńskich relacjach podróżniczych. Poznań: Wydawnictwo Naukowe UAM, 2018.

Schab, Sylwia Izabela. "Wschodnie tropy zbrodni. O Polsce we współczesnej duńskiej powieści kryminalnej." In Dialogi o kulturze, kultura dialogu, eds. Maria Sibińska and Hanna DymelTrzebiatowska, 251-260. Gdańsk: Wydawnictwo Uniwersytetu Gdańskiego, 2018.

Solstad, Dag. Ellevte roman, bok atten. Oslo: Forlaget Oktober, 1992.

Solstad, Dag. Jedenasta powieść, osiemnasta ksiązka, transl. Dorota Polska. Sopot: Smak Słowa, 2011.

Solstad, Dag. Novel 11, Book 18, transl. Sverre Lyngstad. London: Harvill Secker, 2008.

Sveen, Gard. Blod i dans. Bergen: Vigmostad \& Bjørke, 2016.

Sveen, Gard. Roztańczona krew, transl. Karolina Drozdowska. Poznań: Media Rodzina, 2018.

Vika, Mikkel. "Alle vil til Auschwitz." In Nowa Huta, 19-28. Bergen: Vigmostad \& Bjørke, 2016.

Wolff, Larry. Inventing Eastern Europe. Palo Alto: Stanford University Press, 1994.

Electronical resources

Innvandrere og norskfødte med innvandrerforeldre. Statistisk Sentralbyrå, 2019. https://www.ssb.no/innvbef.

Jørgensen, Ola Jostein. Harde liv i Øst-Europa. Littkritikk, 2016. https://www.littkritikk.no/ single-post/2016/09/12/Harde-liv-i-\%C3\%98st-Europa.

Oslo Literary Agency. Accessed November 27, 2019. https://osloliteraryagency.no/.

Audiovisual resources

Brakkefolket. NRK, 2013. https://tv.nrk.no/serie/brakkefolket.

Kampen for tilvorelsen. NRK, 2014/2015.

Sir Winston Churchill - Sinews of Peace (Iron Curtain) Speech. Speech given at Westminster College (Fulton MO) on March 5, 1946. https://www.youtube.com/watch?v=5QuSXZTo3Uo.

\section{THE OTHERS FROM ACROSS THE SEA - EASTERN EUROPEANS AND EASTERN EUROPE IN MODERN NORWEGIAN LITERATURE}

The aim of this article is to present how images of Eastern Europe and Eastern Europeans are constructed in modern Norwegian prose. The theoretical framework of the text is based upon Larry Wolff's Inventing Eastern Europe and Edward W. Said's Orientalism. It can be argued that the European "West" still defines the "East" as an opposition to what it constitutes itself, 
even though the Iron Curtain, represented by the Berlin Wall, came down in the year 1989. Larry Wolff argues that the concept of the Iron Curtain is much older than the curtain itself (which, according to Winston Churchill, divided Europe in 1946), and that is why it still determines people's understanding of Europe as two opposing spaces. Eastern Europe can be therefore perceived as "the Orient" in the sense Said defines this term. This has not changed even in 2004, when many Central European countries joined the European Union, and the political map of the continent was redefined. The article gives a brief summary of the situation of Eastern European minorities in Norway and moves on to the analysis of how these minorities are represented in literature. Six literary works (crime fiction written by Jørn Lier Horst and Gard Sveen, novels by Lars Saabye Christensen, Nina Lykke and Anne B. Ragde and a short story by Mikkel Vika), all published in the years 2004-2017, are analyzed with regards to how images of the space that is Eastern Europe and the people coming from this space are constructed in each book. The article argues that the abovementioned images are built on dichotomic concepts such as modernitybackwardness, wealth-poverty or rationality-irrationality. Finally, the text attempts to present an answer to the question if, why and how the images of Eastern Europeans might change, evolve and transform in Norwegian literature in the future.

KEY WORDS: Norwegian Literature, migrations, minorities, Eastern Europe, exoticization

\section{INNI ZZA MORZA - EUROPA WSCHODNIA I JEJ MIESZKAŃCY WE WSPÓŁCZE- SNEJ LITERATURZE NORWESKIEJ}

Celem niniejszego tekstu jest ukazanie sposobu, w jaki Europa Wschodnia i jej mieszkańcy obrazowani są $\mathrm{w}$ najnowszej norweskiej prozie. Teoretycznym punktem wyjścia rozważań jest praca Larry'ego Wolffa Inventing Eastern Europe oraz klasyczny tekst Edwarda W. Saida Orientalizm. Można wysunąć tezę, że europejski „Zachód” nadal definiuje „Wschód” jako swoje własne przeciwieństwo pomimo tego, iż Żelazna Kurtyna, reprezentowana przez Mur Berliński, fizycznie upadła w roku 1989. Larry Wolff wysuwa w swojej książkę teorię, iż koncepcja Żelaznej Kurtyny jest dużo starsza niż ona sama (tj. niż metaforyczna kurtyna, która, wg. słów Winstona Churchilla, zapadła nad Europą w roku 1946) i że dlatego też koncepcja ta nadal dyktuje sposób myślenia o Europie jako kontynencie składającym się z dwóch przestrzeni istniejących w opozycji do siebie. Europa Wschodnia może być zatem postrzegana jako coś w rodzaju „Orientu”, tak, jak zdefiniował ten termin Said. Nie zmienił tego nawet rok 2004, kiedy Unia Europejska poszerzyła się o szereg krajów Europy Centralnej, a polityczna mapa kontynentu uległa redefinicji. Artykuł przedstawia pokrótce sytuację wschodnioeuropejskich mniejszości w Norwegii, przechodząc następnie do analizy tego, jak mniejszości te obrazowane są w najnowszej norweskiej literaturze. Analizie zostaje poddanych sześć tekstów literackich opublikowanych w latach 2004-2017 (kryminały Jørna Liera Horsta i Garda Sveena, powieści Larsa Saabye Christensena, Niny Lykke i Anne B. Ragde oraz opowiadanie Mikkela Viki). Badanie dotyczy tego, jak w wybranych tekstach zostaje ukazana sama przestrzeń Europy Wschodniej oraz jak obrazowani są ludzie z tej przestrzeni pochodzący. Zostaje wysunięta teza, iż literackie obrazy oparte są na parach przeciwstawnych pojęć takich jak nowoczesność-zacofanie, bogactwoubóstwo czy racjonalność-irracjonalność. W artykule zostaje również podjęta próba odpowiedzi na pytanie, czy oraz ewentualnie jak i dlaczego obrazowanie Europy Wschodniej i pochodzących z tego rejonu świata ludzi w norweskiej literaturze może z czasem ulec zmianie.

SŁOWA KLUCZOWE: Literatura norweska, migracje, mniejszości Europa Wschodnia, egzotyzacja 